\title{
International Migration Diversity in Hungary in the 2011 Population Census Data
}

\author{
Áron Kincses Foreign nationals have had a significantly positive \\ Hungarian Central Statistical influence on the regional socioeconomic \\ Office developments of Hungary. Two realignments took \\ E-mail: place between the last two censuses: at first, the \\ aron.kincses@ksh.hu composition of citizenship changed; then, the local \\ redistribution changed partly because of the \\ different structure of citizenship. \\ Fields of interests and research: Regional science, \\ regional geography, regional and urban \\ development, regional analysing methods, social- \\ and economic geography network-analysis, applied \\ mathematics and the application of physical science \\ Keywords: models in geography. \\ international migration, \\ census, \\ dual citizenship
}

\section{Introduction}

Migration is an interdisciplinary topic that mainly interests the fields of demography, statistics, geography, law, economic science, history, work science, psychology, and political science. Consequently, its definition and interpretation emphasise numerous forecasted projections. The Demographic Yearbook published by the Hungarian Central Statistical Office (HCSO 2008) defines international migration as the permanent abandonment of the original (usual) country of residence with the goal of settling down, residing, or obtaining gainful employment in another country.

Because motivations to migrate are continually evolving, definitions of settlement or performing gainful activity have expanded to include the ideas of educational purposes (Rédei 2007) and elderly migration (i.e. the motivation to improve the purchasing power of pensions, increase recreational opportunities, or obtain a relatively more favourable climate) (Illés 2008). The motivation to achieve family reunion also is emphasised as a major factor in international migration.

The core assumption of extant interpretations of historical migration is that migration is a singular event in a person's lifetime. In this sense, migration is a relatively rare occurrence, and it can be characterised as a type of extraordinary event. 
This migration determines migrants' lives because this unique, unidirectional event is linked to the symbolic moment of crossing a border (Kovács-Melegh 2000).

However, the effects of migration on migrants depend on the socioeconomic contexts at the points of origin and destination where it occurs; moreover, they inevitably bear the characteristic features of their historical contexts. In the present era of globalization, income gaps among countries are increasing at an accelerated rate, and development is uneven (Kofman-Youngs 2003). The widening differences in the quality of life between poor and rich countries are encouraging human migrations. Simultaneously, migrants' financial assets continue to increase, and spatial access is improving. Furthermore, some areas of the world are converging such that the cost of long distance migration relative to household income has become so low that growing numbers of people in peripheral countries are finding it feasible to migrate (Hatton-Williamson 2005). In this context, the advent of omnipresent information and transportation technologies and increased border penetrability has meant easier border crossings. The phenomena of circular migration and transnational migration also have appeared on the international scene. Cross-border migrations decreasingly determine the intention to finally settle down (Hatton-Williamson 2005), but rather can be considered as a station within lifetime.

The purpose of this study is to challenge historical interpretations of migration behaviours using 2011 population census data and to describe the immigration groups in Hungary. The study describes the geographic locations of Hungarian migrants as well as their demographic, labour market, and educational attainment differences from the Hungarian native population, and it discusses possible causes for their residential choices. Understanding the full complexity of the topic demands a sophisticated analysis that is beyond the scope of this study. Therefore, although not exhaustive, this study focuses on some key aspects of the Hungarian immigration situation.

\section{Content of analysis, main migration groups}

For conceptual and practical reasons, the terms voluntary and legal migration refer to international migration in which migrants change their places of residence (at their volition) from another country and their choices depend on their self-evaluated internal factors, external factors, and attractive and repulsive effects. Most studies on migration consider only foreign citizens or citizens born abroad, although international migration is much broader. To address this weakness and take advantage of the full scope of the population census data, which covers total population of a given area (country) and relates to a predetermined point of time, the paper distinguishes among four migrant groups: foreign citizens, citizens born abroad, dual citizens (Hungarian plus at least one other national citizenship), and Hungarian citizens returning bome.

Regional Statistics, Vol 5, No 2. 2015: 108-124; DOI: 10.15196/TS05206 


\section{Foreign citizens and citizens born abroad}

Citizenship laws throughout the world bind citizenship to the principles of ius sanguinis (privity) or ius soli (country of birth). In the first case, parental citizenship is decisive to determine citizenship, whereas, in the second case, country of birth is the determining factor. However, variation among national laws means that if a citizen of a country of origin under ius sanguinis bears a child in a country that relies on ius soli, that child obtains dual citizenship at birth. On the other hand, if a child is born in a country under the principle of ius sanguinis and the parents are from a country relying on ius soli, neither country would recognize that child as a citizen. Hungary is similar to most European countries in that it confers citizenship under ius sanguinis. According to Act LV of 1993 on Hungarian Citizenship (with amendments), only children whose parents are Hungarian citizens are Hungarian citizen at birth. Hungarian citizenship also can be acquired through the process of naturalization (for individuals who are not born as Hungarian citizens) or re-naturalization (for individuals whose previous Hungarian citizenship has ceased).

In 2011, Hungary's foreign citizens were included in the population census if they had been living in the country for at least 12 months at the reference date or if they intended to live in Hungary for at least one year, and if, besides their foreign citizenship, they were not Hungarian citizens. Members of the foreign diplomatic corps and their families, members of foreign armed forces stationed in the country by governmental or National Assembly decisions, and persons in Hungary as tourist visitors, for medical reasons, on business, and so on were not enumerated. ${ }^{1}$

In this study, individuals born outside Hungarian borders and habitually residing inside Hungary are considered foreign-born citizens. This group might include foreign-born foreigners, Hungarians born abroad, those born as Hungarian citizens, foreign-born naturalized Hungarians, and foreign-born repatriated Hungarian citizens.

\section{Dual citizens}

Early in the twentieth century, migrants only sporadically travelled home or transferred money home to the country of origin (Rédei 2007). Over time, these became monthly, weekly, or daily practices. The possibilities of maintaining personal contact without spatial mobility changed from being monthly to immediate events (from letters to telegraph to telephone to e-mail, and, recently, to Skype). Thereby, the economic, social, cultural, and political activities of the host and origin countries were increasingly interconnected (Viszt et al. 2001, Portes-DeWind 2004, Walton-

\footnotetext{
${ }^{1}$ http://www.ksh.hu/nepszamlalas/docs/modszertan.pdf
} 
Roberts 2004, Rédei 2005, Williams-Balaz 2008). Consequently, the characteristics of migration changed.

In the era of globalization, numerous plural phenomena are observed, such as multiple:

- residences,

- citizenships,

- real estate ownerships,

- employments,

- identities,

- loyalties (Waldinger 2008).

In many countries, exclusive national citizenship has been degraded by the elimination of compulsory military service, treaties that end double taxation, and supranational rules of economic integration, even before the recognition of dual citizenship. Transnationalism reached a higher quality level because of the globalization processes of burgeoning travel and communication technologies (Bernek 2002).

An early understanding of migration held that the process of international migration involves at least two independent political states in which a migrant secedes from the releasing state and accedes to the host country. In the concept of transnational migration, dual citizens (in the within analysis these are persons with foreign citizenship plus Hungarian citizenship) are connected to both countries through their work, residences, and other activities, (Waldinger 2008), and they have the language skills and local knowledge of both regions.

\section{Hungarian citizens returning home}

A fundamental approach of historical studies to migration is that migration is a unique event in a person's lifetime and it, therefore, has an extraordinary character. Knowledge of new types of migration (as discussed above) challenges the notion that migration is a unique event, such as losing citizenship of the country of origin and acquiring citizenship of a host country (Bonancich 1972). In this process, crossborder migrations decreasingly mean the intention to finally settle down, but rather they can be found as a station of lifetime.

Migration, from a spatial perspective, could be considered a process because areas of origin and destination are interconnected. According to the spatial scientific approach (Nemes Nagy 2009), migration is separated in area, to which, when a dual time dimension is attached (synchronous-asynchronous), two possibilities arise. First, there will be separate space-synchronous and separate space-asynchronous migration systems. The first separate-space-synchronous migration system will be assigned to the most attractive centres. These core areas practically detect synchronous streams within the borders of their attraction. In global terms, there are three of these centres: Canada and the United States in North America, the European Union in Europe, and

Regional Statistics, Vol 5, No 2. 2015: 108-124; DOI: 10.15196/TS05206 
Australia in the Pacific Ocean. To characterize separate space-asynchronous migration systems, a minimum of two attractive centres is necessary, between which the simplest migration system comprises two interconnected processes: migration to somewhere and remigration. When a starting point has no posterior attraction for the migrant, neither does the place of migration meet his expectations, and a third location could advance to the second place of attraction (Illés-Kincses 2009).

\section{Citizens born abroad, foreign citizens and dual (Hungarian and other) citizens}

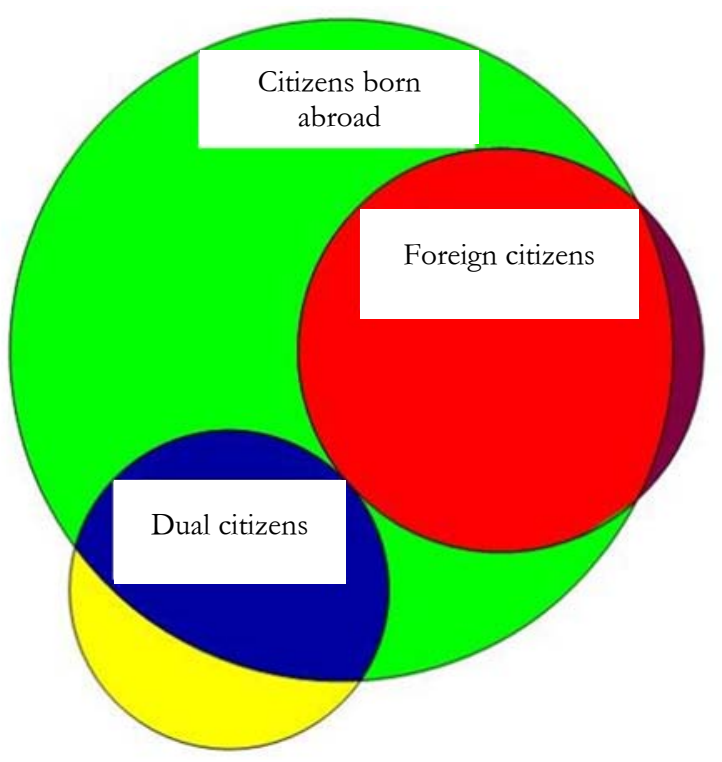

Figure 1

Some Hungarian citizens who leave Hungary do not leave their home country forever; Ravenstein (1885) suggests that each significant migration flow creates a reflection, which is its counterflow, at a temporal phase shift, and migrants return after a time lag, by separate-space-asynchronous migration. In this study, Hungarian citizens returning home (returnees) are those Hungarians who had been living at least one year during their lifetimes permanently outside the territory of present-day Hungary, were not born abroad, and had habitually settled in Hungary.

\section{Migrant groups in Hungary}

Foreign-born citizens include individuals who have only foreign citizenship and those with dual citizenship (see Figure 1, 3, 4). Independent examination of this group is justified because the Act on Hungarian Citizenship (ius sanguinis) categorizes as dual citizens 25,554 of those born abroad. Of those who have only foreign citizenship, 7254 were born in Hungary. Compared to the more than 200,000 persons enumerated in the 
previous census, the 2011 population census counted fewer foreign citizens. A possible reason for this change is that the earlier count included foreign citizens and dual citizens. At the theoretical time of zero hour on 1 October 2011, Hungary had 143,197 foreign citizens (excluding dual citizens) and 383,236 foreign-born citizens. For both groups, most people migrated from neighbouring countries or from Germany. Europe plays an outstanding part in Hungarian migration, particularly regarding foreign-born migrants. About 90\% of the migrants in 2011 originated from Europe.

The significant number from neighbouring countries relates to cross-border linguistic and cultural connections. This fact suggests that the effects of peace treaties formed at the ends of World Wars I and II strongly influence migration processes in the Carpathian Basin (Tóth 2005). Political changes during the 1990s relate to ethnic Hungarians' mass migrations into and out of Hungary. In the first year of the regime change resulting in Romania's anti-minority policy and the incidents in Timisoara, Hungary faced strong migration pressures, which were repeated during the Yugoslav wars. Forced migration transformed into voluntary migration for business or educational purposes.

Interestingly, the number of people born in Romania and living in Hungary is greater than the population of Szeged. Hungary is a primary destination for Europeans, and relatively short distance international migrations are typical. However, the number of Asian and African American migrants is significant because foreigners living in Hungary comprise 161 different nationalities born in 195 different countries (including associated countries and external territories).

Dual citizens and Hungarian citizens returning to Hungary are automatically considered Hungarian citizens by most sources. The reason for this is lack of data, and the only reliable source of information is the population census. According to the census, 88,906 persons of Hungarian citizenship had an additional citizenship in 2011. The distribution of this group resembles the distribution of foreign citizens, in which European origins are clearly observed. This phenomenon indicates that an areaindependent interconnectivity of economic, social, cultural, and political factors between sending and host states is limited. Regarding the origins of the dual citizens, Asians and Africans are underrepresented and Australia and the Americas are overrepresented compared to the distribution of foreign nationals' origins. In Hungary, the numbers of American-, Canadian-, or Australian-Hungarian citizens are higher than those of the American, Canadian, or Australian foreign citizens, respectively, suggesting that most of the migrants from those places have Hungarian roots.

There is no exact information on the number and composition of people emigrating from Hungary. Most studies that address emigration rely on representative samples for surveys or on foreign administrative databases. In both cases, the number of Hungarian emigrants is probably overestimated. In the samples, mode effects and high sampling errors due to small sample size limit generalization, and, in the second case, duplication and cumulative errors could yield unrealistic results. Regarding the number of Hungarian citizens living abroad, few accurate estimations exist (Gödri

Regional Statistics, Vol 5, No 2. 2015: 108-124; DOI: 10.15196/TS05206 
2010, Kapitány-Rohr-2013). These studies estimate the number of Hungarians living abroad not in the millions, but in the hundreds of thousands. Without precise knowledge on emigration, it is important to emphasise the census results, according to which a significant portion of the emigrants does not necessarily cause a demographic loss for Hungary because 190,204 persons were registered in Hungary who had been living abroad for at least a year but had returned home and settled in Hungary (see fig. 1.).

Hungarians returning home are not just a demographic surplus for Hungary because language skills and foreign experience suggest an important advantage in the labour market (Rédei 2007). This is where new types of migration might be captured, i.e., the separate space-asynchronous migration systems in which Hungary is defined by migrants as an attractive remigration centre. An examination of Hungarian citizens returning to Hungary does not indicate precisely where and when these Hungarians emigrated nor does it inform us of the main foreign centres at that time. However, the data do show the countries to and from which these Hungarians migrated.

Figure 2

\section{Hungarian citizens returning home by year of return}

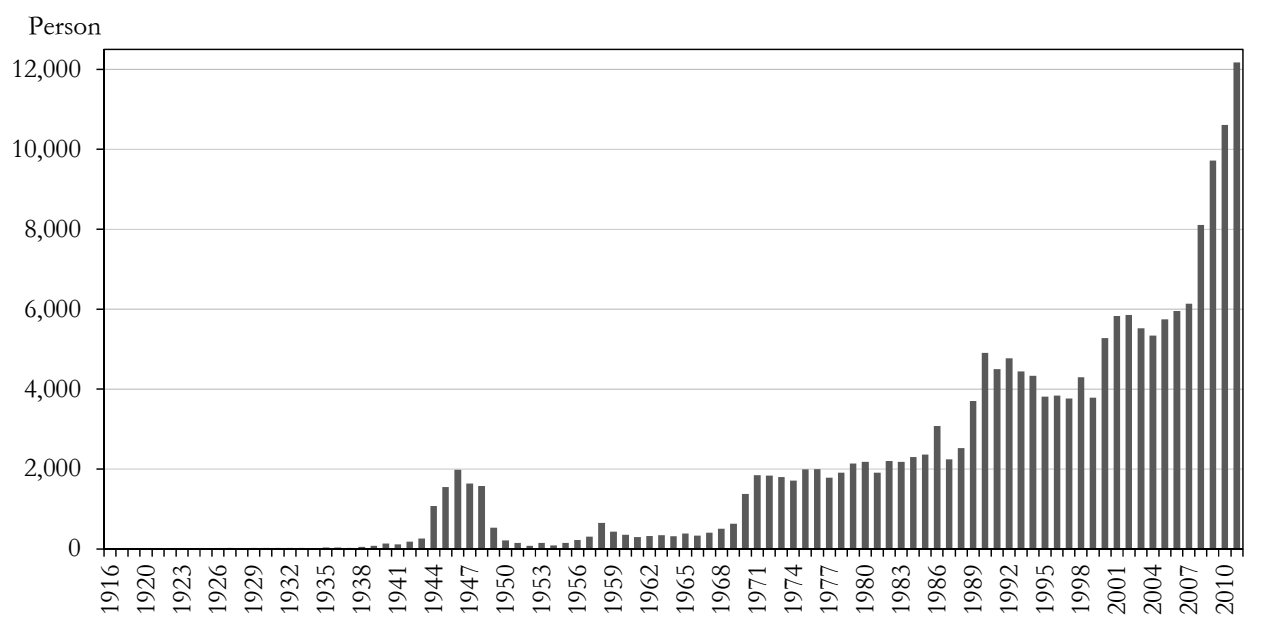

Until the end of World War II, returnees were mostly from neighbouring countries because of the homeland role. Between 1945 and 1980, because of the establishment of socialist state apparatuses, the largest numbers of returnees to Hungary were from Russia, Iran, Mongolia, Egypt, Germany (GDR), and Austria. From 1981 until the regime change, returnees arrived mostly from Germany, Russia, Algeria, Austria, Iraq, and Libya. After 1990, because of the regime change, the countries from which Hungarians were returning changed. The US and Canada joined Austria and Germany (mostly emigrants from 1956), followed by the UK in 2004 (emigrants returning after 1990 is the most probable case). Accession to the EU and the labour market

Regional Statistics, Vol 5, No 2. 2015: 108-124; DOI: 10.15196/TS05206 
expansion are assumed to have caused the growth in the number of migrants; with a time lag, the number of returnees also is significantly increasing, which process was influenced by the economic crisis and associated decline in employment in Western Europe (see Table 1).

Table 1

Migrants living in Hungary by group and by country of former residence, 2011

\begin{tabular}{|c|c|c|c|c|}
\hline $\begin{array}{l}\text { Country of } \\
\text { citizenship/birth of } \\
\text { migrant/country of } \\
\text { former residence before } \\
\text { returning to Hungary }\end{array}$ & $\begin{array}{c}\text { Dual citizens } \\
\text { (Hungarian and } \\
\text { other) }\end{array}$ & $\begin{array}{l}\text { Foreign } \\
\text { citizens }\end{array}$ & $\begin{array}{l}\text { Born } \\
\text { abroad }\end{array}$ & $\begin{array}{c}\text { Hungarian } \\
\text { citizens who } \\
\text { lived abroad } \\
\text { one year or less } \\
\text { before returning } \\
\text { to Hungary }\end{array}$ \\
\hline Romania & 39,270 & 38,574 & 176,550 & 4,478 \\
\hline Germany & 6,412 & 16,987 & 22,605 & 51,911 \\
\hline Slovakia & 1,679 & 8,246 & 33,155 & 2,835 \\
\hline Austria & 1,467 & 3,936 & 6,160 & 11,376 \\
\hline United Kingdom & 1,627 & 2,602 & 3,597 & 20,949 \\
\hline France & 1,298 & 2,201 & 3,233 & 5,214 \\
\hline Netherlands & 762 & 2,058 & 2,438 & 3,712 \\
\hline$E U-28$ & 59,644 & 85,414 & 266,701 & 123,181 \\
\hline Ukraine & 2,383 & 11,820 & 35,354 & 3,133 \\
\hline Serbia & 9,394 & 7,752 & 29,144 & 1,529 \\
\hline Europe (other) & 3,434 & 7,536 & 13,608 & 23,153 \\
\hline Europe total & 74,855 & 112,522 & 344,807 & 150,996 \\
\hline China & 952 & 8,852 & 8,767 & 603 \\
\hline Vietnam & 783 & 2,358 & 2,668 & 181 \\
\hline Iran & 146 & 1,523 & 1,713 & 232 \\
\hline Asia (other) & 2,240 & 9,571 & 12,358 & 8,944 \\
\hline Asia total & 4,121 & 22,304 & 25,506 & 9,960 \\
\hline United States & 4,978 & 3,022 & 4,684 & 15,970 \\
\hline Canada & 2,149 & 484 & 1,198 & 4,433 \\
\hline Americas (other) & 741 & 1,237 & 2,416 & 1,621 \\
\hline Americas total & 7,868 & 4,743 & 8,298 & 22,024 \\
\hline Nigeria & 128 & 1,015 & 1,101 & 507 \\
\hline Egypt & 168 & 472 & 632 & 778 \\
\hline Africa (other) & 679 & 1,366 & 2,256 & 3,920 \\
\hline Africa total & 975 & 2,853 & 3,989 & 5,205 \\
\hline Other and unknown & 1,087 & 775 & 636 & 2,019 \\
\hline Total & 88,906 & 143,197 & 383,236 & 190,204 \\
\hline Hungary & 88,906 & - & & 190,204 \\
\hline
\end{tabular}

Regional Statistics, Vol 5, No 2. 2015: 108-124; DOI: 10.15196/TS05206 
Foreign born persons living in Hungary by country of birth, 2011

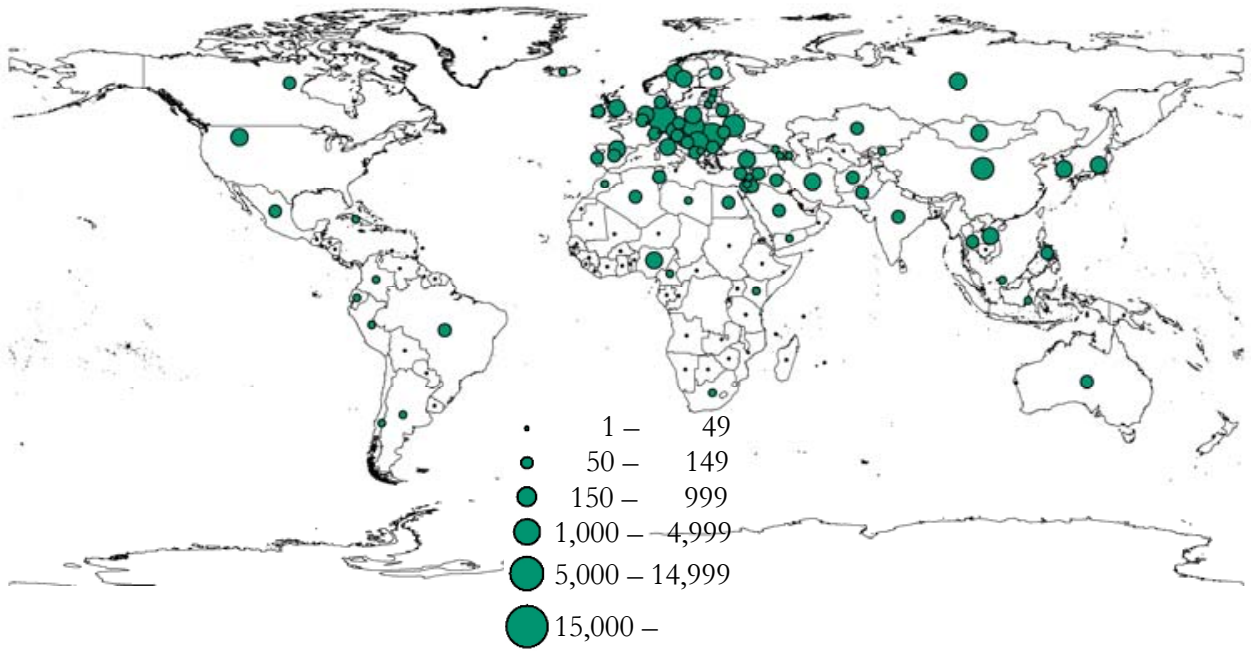

Figure 4

Hungarian citizens returning home by country of foreign residence, 2011

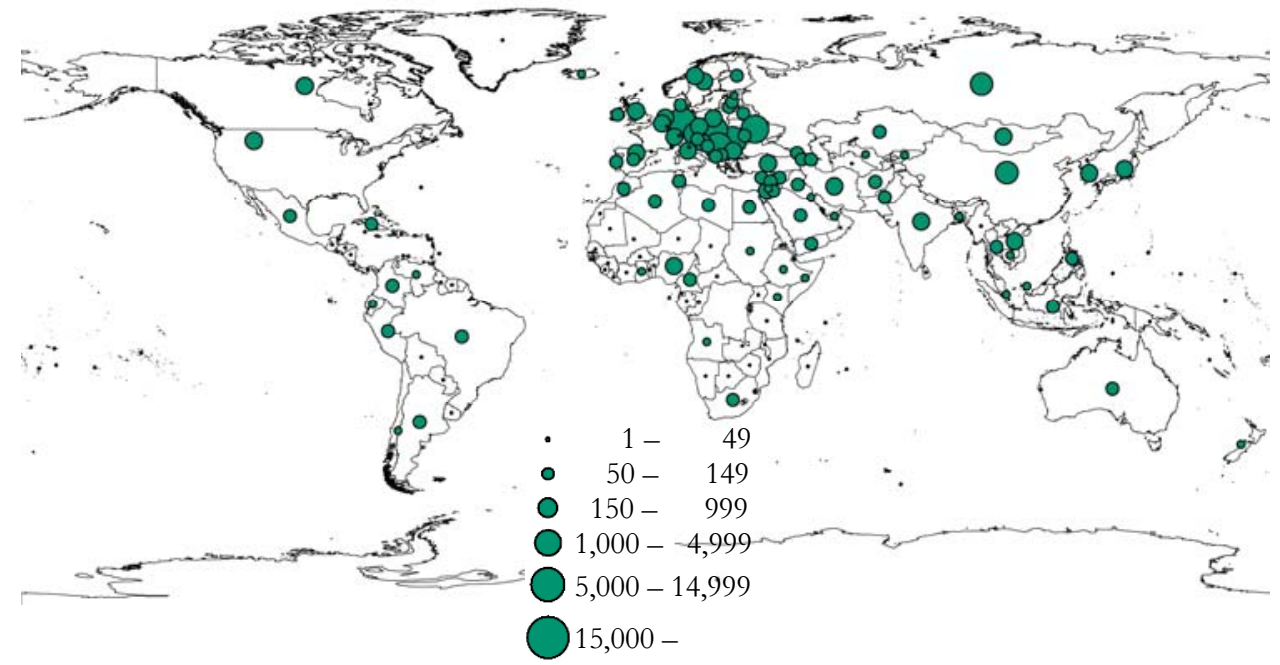

\section{Demographic and labour market characteristics of migrant groups}

Most previous studies highlight that migrants are relatively young (Gödri 2012) compared to the resident population in Hungary, and migration has, therefore, rejuvenated Hungary. The average ages of male and female foreign nationals living in 
Hungary are 38.0 and 39.6 years, respectively; in the overall population, males and females are 39.3 and 43.5 years, respectively. For dual citizens, the difference is slightly less pronounced (average age is 39.2 years), whereas citizens born abroad are 47.4 years on average, and Hungarian citizens returning home are 47.6 years on average. The two latter groups are older than the average resident population. More than onequarter of Hungarian citizens born abroad is older than 65 years of age. The majority of working-age adults who migrated to Hungary in large numbers in the 1990s belongs to this age group. For Hungarian returnees, the average age is relatively old because few of them are under the age of 24 , suggesting that most of the migrants leave Hungary for employment (see Figure 5).

\section{Migrants by age groups, 2011}

Figure 5

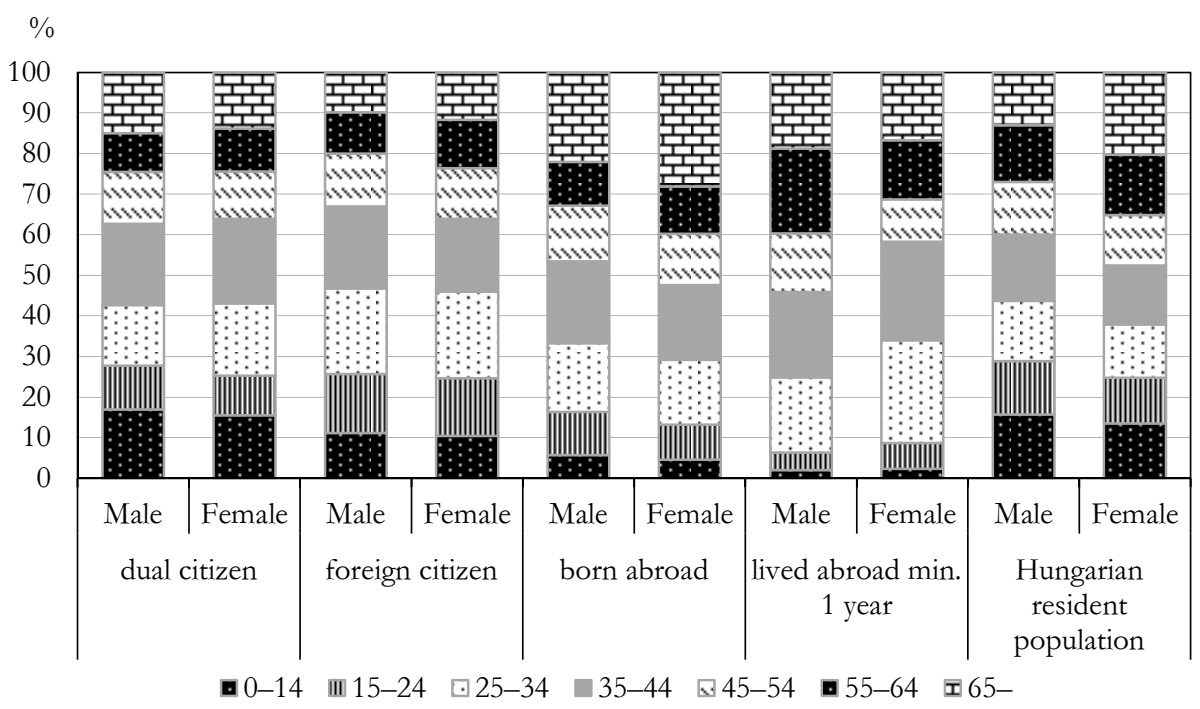

Population census data confirm the results of previous studies regarding migrants' characteristics. Migrants are, on average, better educated and more economically active than the Hungarian population (non-migrant resident population), providing a human and economic surplus for Hungary (Kincses 2012). Nearly one-third of the foreign and foreign-born populations over age 24 , more than $40 \%$ of persons with dual citizenship, and almost one-half of Hungarian returnees have higher educational attainment than non-migrant Hungarian nationals (see Figure 6).

Migrant groups' relatively higher educational attainments and higher proportions of working-age people relate to their relatively higher employment rates compared to the Hungarian resident population. The unemployment rate is lowest for foreign citizens and highest for Hungarian returnees, which is similar to the rate of the resident population. In Hungary, only about $0.4 \%$ of inactive earners live on their

Regional Statistics, Vol 5, No 2. 2015: 108-124; DOI: 10.15196/TS05206 
assets (see Table 2). The same rate for Hungarian returnees is $1.3 \%$; it is $1.8 \%$ for those born abroad, $3.1 \%$ for dual citizens, and 3.3\% for foreigners. Within the dependents of the resident population aged 25-64 years, 10\% are full-time students, whereas, for the surveyed migrant groups, the rate is between $14 \%$ and $23 \%$.

Figure 6

Migrant groups (aged over 25 years) by educational attainment, 2011

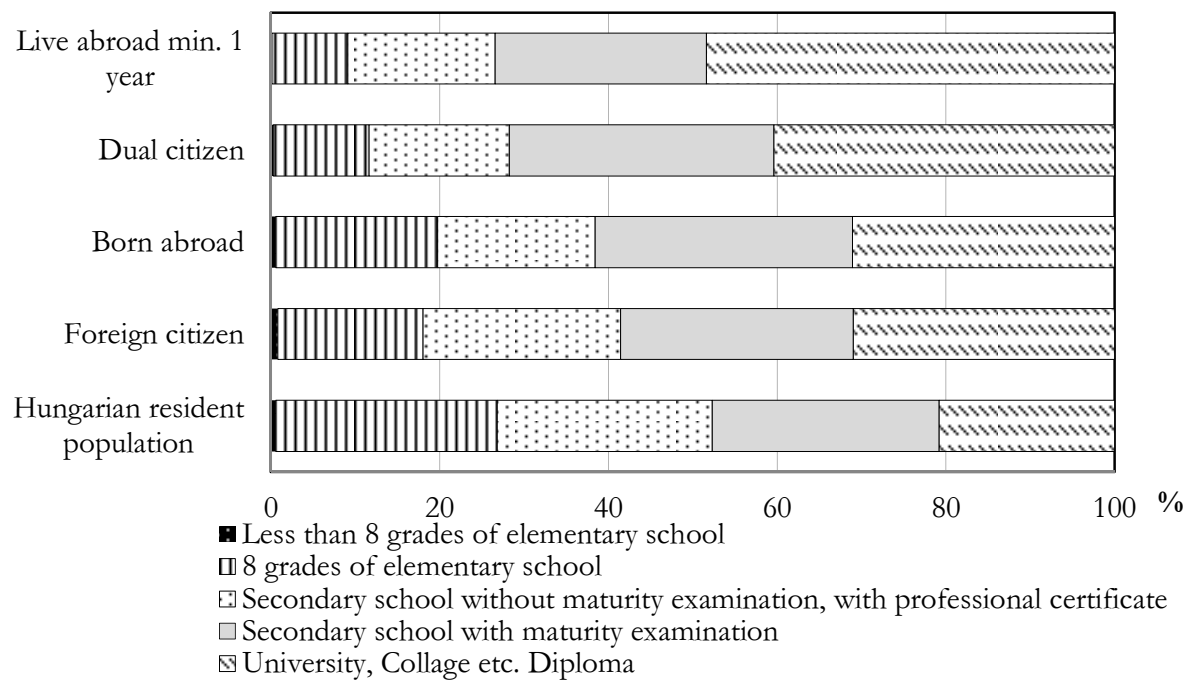

Distribution of migrants aged 25-64 years and of

Table 2 resident population by economic activity

\begin{tabular}{l|r|r|r|r|r}
\hline & Dual & Foreign \\
Economic activity & $\begin{array}{c}\text { Ditizens } \\
\text { citizens }\end{array}$ & $\begin{array}{c}\text { Born } \\
\text { abroad }\end{array}$ & $\begin{array}{c}\text { Hungarian } \\
\text { citizens who } \\
\text { lived abroad } \\
\text { one year or } \\
\text { less before } \\
\text { returning to } \\
\text { Hungary }\end{array}$ & $\begin{array}{c}\text { Hungarian } \\
\text { resident } \\
\text { population }\end{array}$ \\
\hline Employed & 72.6 & 70.2 & 72.2 & 68.4 & 64.4 \\
Unemployed & 7.4 & 4.6 & 6.6 & 9.0 & 8.7 \\
$\begin{array}{l}\text { Economically active population } \\
\text { total }\end{array}$ & 80.0 & 74.8 & 78.8 & 77.4 & 73.1 \\
$\begin{array}{l}\text { Inactive earner } \\
\text { Dependent }\end{array}$ & 14.3 & 15.7 & 15.7 & 17.4 & 23.1 \\
Economically inactive & 5.7 & 9.5 & 5.5 & 5.2 & 3.8 \\
population total & 20.0 & 25.2 & 21.2 & 22.6 & 26.9 \\
\hline \multicolumn{1}{|c|}{ Grand total } & 100.0 & 100.0 & 100.0 & 100.0 & 100.0
\end{tabular}


A comparison of current and most recent occupations shows that all of the migrant groups are proportionally dominant over the resident population in the more prestigious business, senior governmental, legislative, and professional occupations requiring third level educational attainment. The reverse situation is observed for elementary occupations, plant and machine operators, assemblers, vebicle drivers, agricultural workers, and forestry occupations, which represent lower value added (see Figure 7).

\section{Distribution of migrants aged 25-64 years in resident population by main occupational groups, 2011}

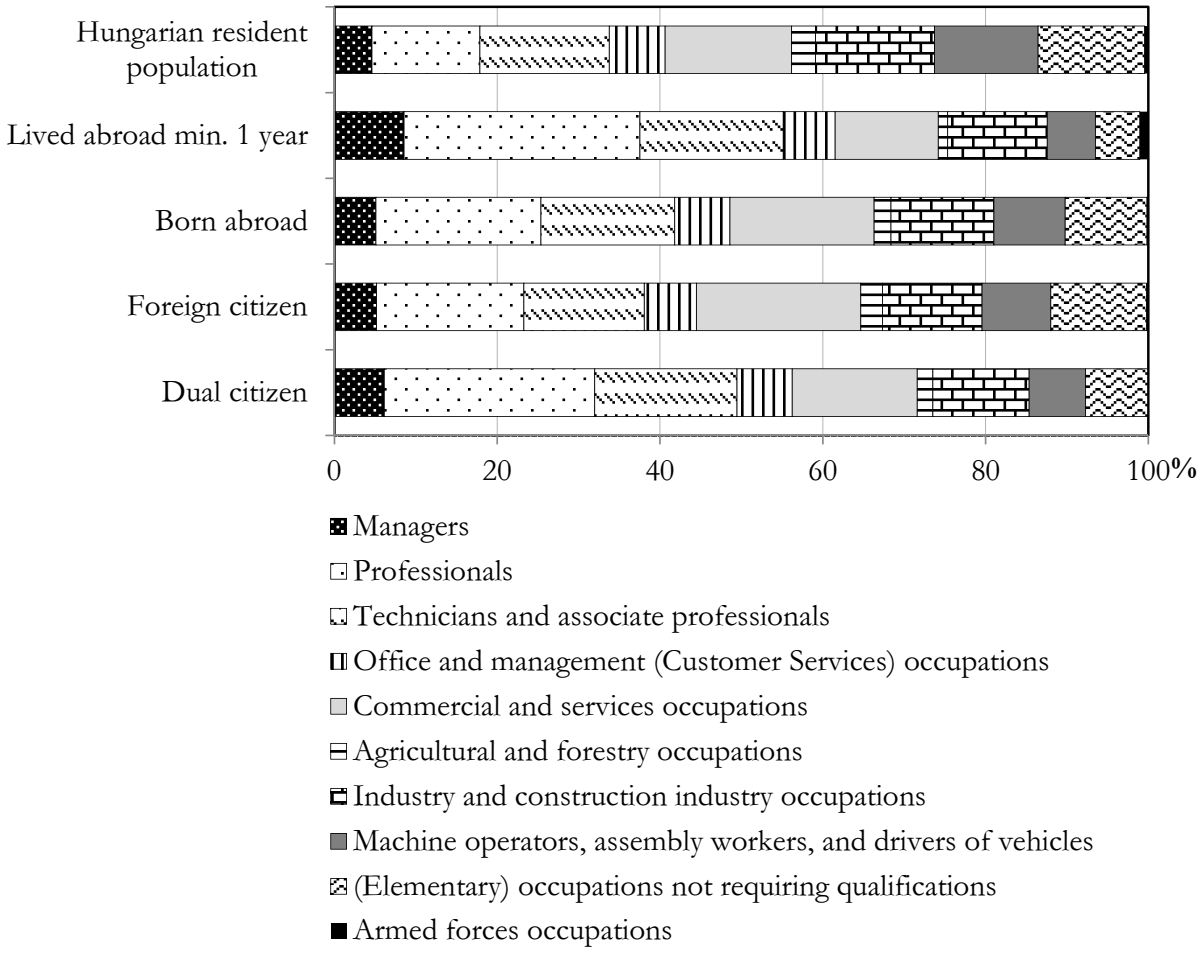

\section{Spatial overview}

Because the spatial distributions of migrant groups differ from that of the Hungarian resident population, the influences of migrants on the country might be less than they are in the specific areas where migrants tend to cluster. Social groups with relatively high prestige and better skills in higher paid occupations tend to concentrate in areas with relatively strong economic indicators and more favourable social images, thereby reinforcing the significant differences in spatial social structure typical of Hungary, in 
which there is segregation and concentration of socioeconomic groups by prestige (Németh 2011). Three Hungarian regions are of particular interest from the migration perspective, which are generally and persistently typical of Hungary's migrant groups: central Hungary, border districts, and the Lake Balaton region.

Budapest and Pest County (Central Hungary) attract foreigners from far away, and the residents of this area are mostly non-European migrants. There are many employed persons, the average age is relatively young, and educational attainment is relatively high. In this area, the residents are mostly highly qualified, economically active foreign citizens. During the past ten years, Budapest has become a global migration target area.

In Hungary, most foreign citizens migrate from neighbouring countries, and the location of target areas plays a decisive part in the regional distribution of migrants. Border district areas play an important part in addition to the economic centres with respect to the selection of a place to live. These settlements are not particularly diverse in the composition of citizenship types, and the population mostly comprises people migrating from across the border.

The Lake Balaton region is mainly attractive to German, Austrian, Dutch, Swiss pensioners, and elders seeking new locations to improve their pensions' purchasing power, increase recreation, and enhance natural value. In addition, foreigners tend to find it easier to integrate into village than city life. The number of elderly migrants significantly increased between the two censuses (see Figure 8-12).

\section{Distribution of migrant and resident population by the present legal status of residence, 2011}

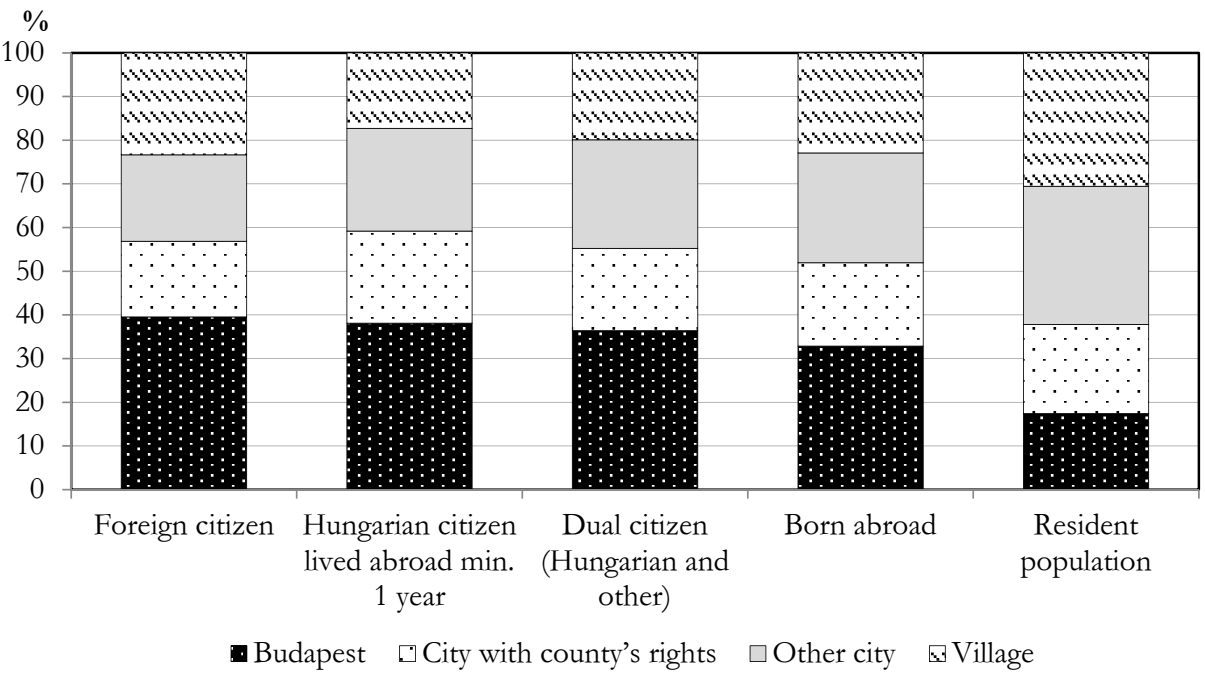

Regional Statistics, Vol 5, No 2. 2015: 108-124; DOI: 10.15196/TS05206 
Proportion of foreigners per 100 population, 2011

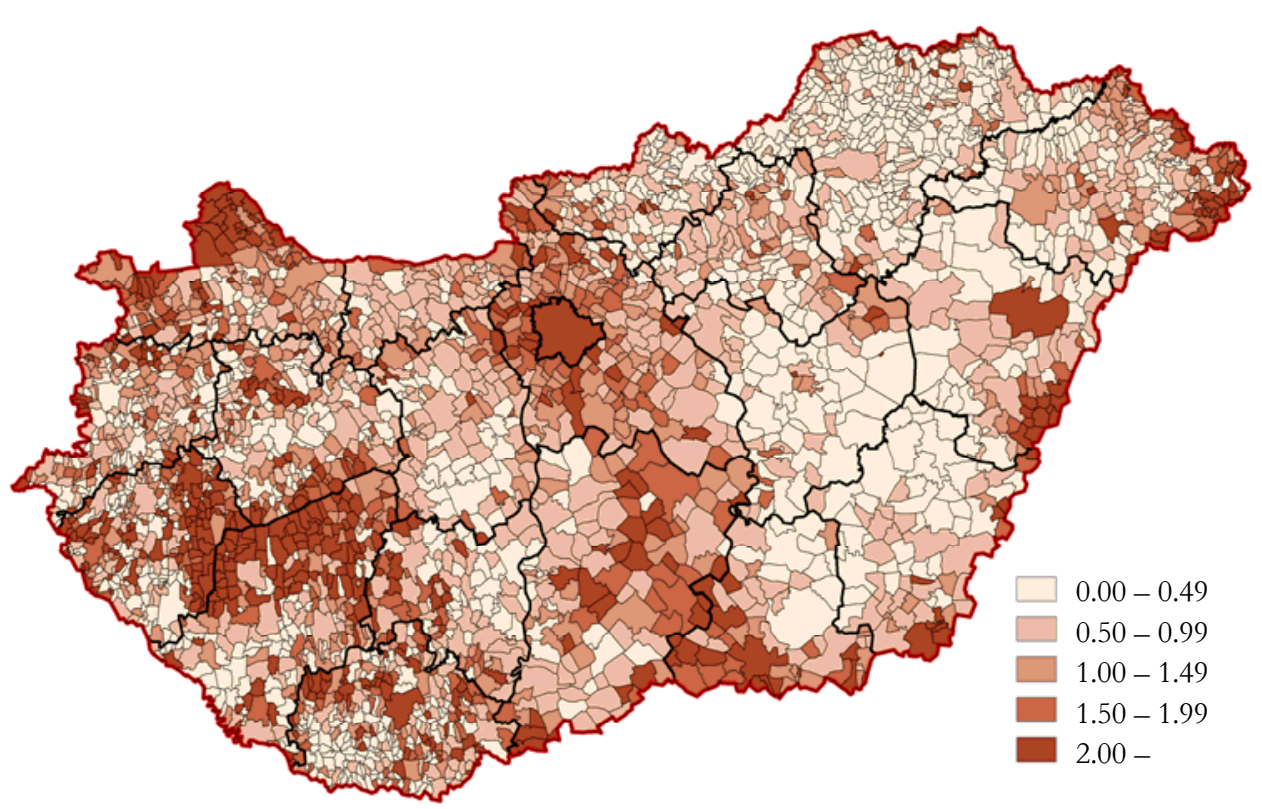

Figure 10

Proportion of dual citizens per 100 population, 2011

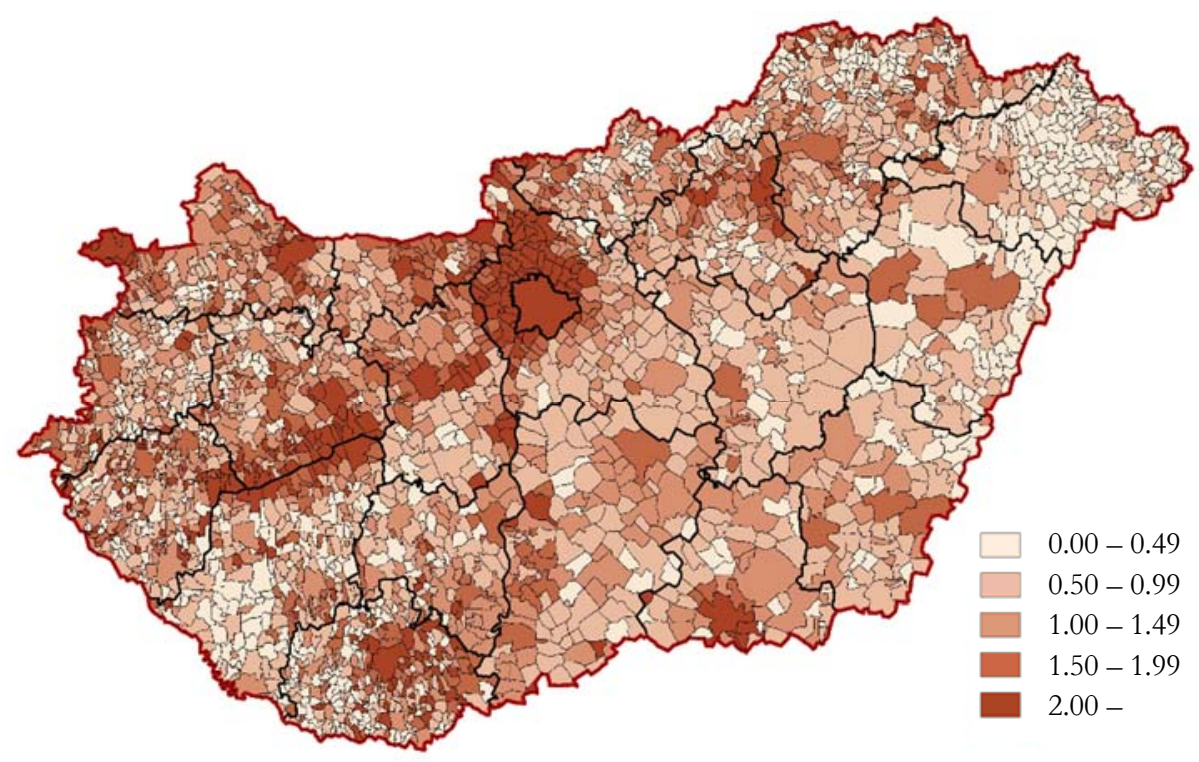

Regional Statistics, Vol 5, No 2. 2015: 108-124; DOI: 10.15196/TS05206 
Proportion of citizens born abroad per 100 population, 2011

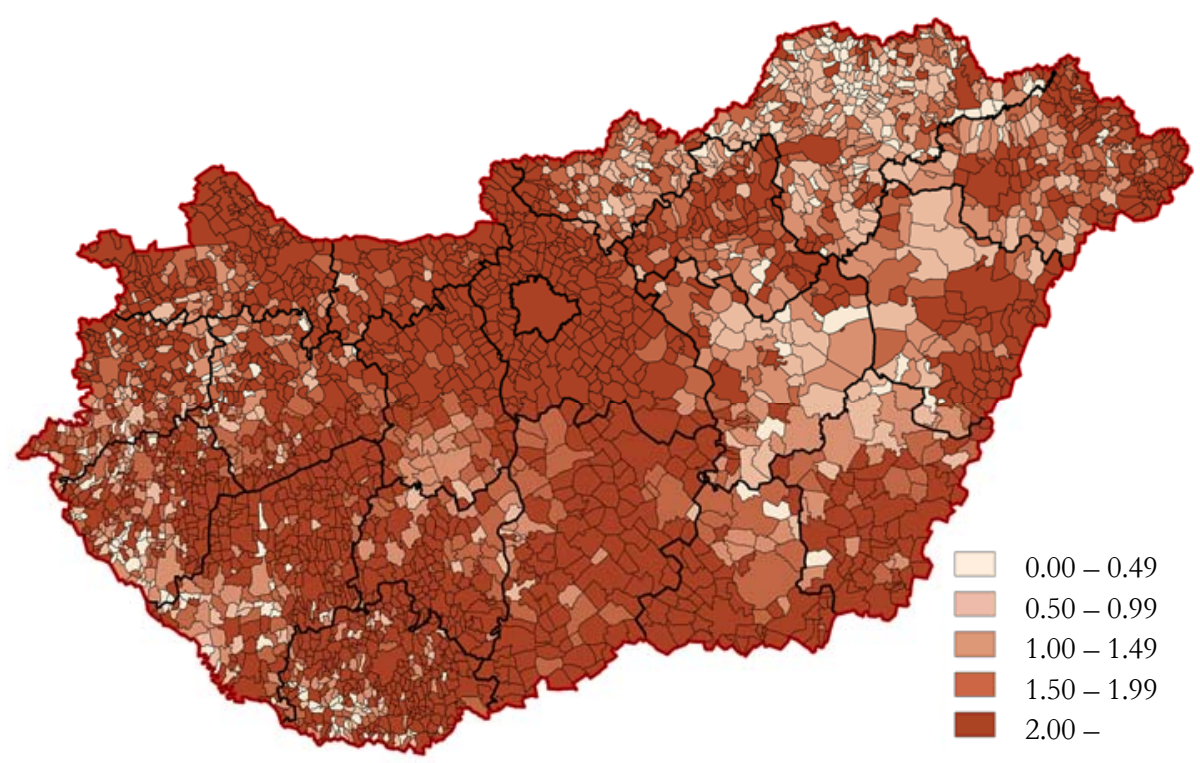

Figure 12

Proportion of Hungarian returnees per 100 population, 2011

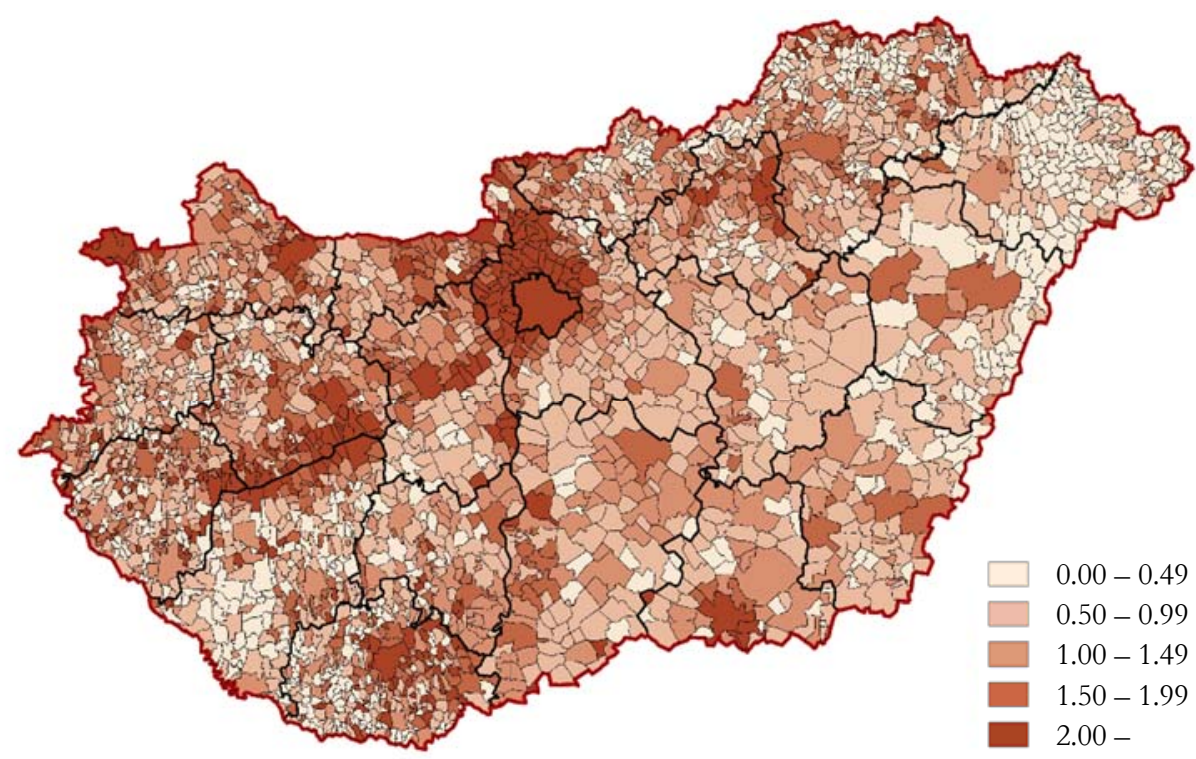

Regional Statistics, Vol 5, No 2. 2015: 108-124; DOI: 10.15196/TS05206 
It is typical of the spatial distribution of Hungarian returnees that about $30.7 \%$ of them returned to the locations of their previous Hungarian residences. Hungarian returnees clearly demonstrate migrant attitudes when choosing a place to live. Underlying this phenomenon is an important factor: The Hungarian non-migrant population is less flexible in choosing a place of residence than the migrant population because it is more place-bound by family and cultural ties, and local patriotism can impede the frequency, distance, and direction of relocations. In the case of returnees, however, the image of local settlement stock can be an important explanatory factor.

\section{Summary}

In Hungary, the number and proportion of migrants in the population are continually increasing. There are two fundamental reasons. On the one hand, the size of the resident Hungarian population is decreasing, which increases the migrants' proportional representation. On the other hand, the number of foreign-origin migrants is increasing. Foreign citizens began entering Hungary in significant numbers after the regime change. In the initial period, migrants were mostly ethnic groups of Hungarian nationality. Following accession to the European Union, globalisation influenced Hungarian migration networks such that the number of Hungary's migration sources expanded, and technological changes attracted foreign citizens from farther away. Foreigners living in Hungary comprise about 161 different citizenships born in 195 different countries (including associated countries and external territories).

Currently, the homeland role of the Carpathian Basin, the minority policies of neighbouring countries, transnationalism, multiple identities and multiple citizenships, new types of migration, and circular migration are simultaneously present and active in Hungary. Consequently, international migration cannot be understood as one-dimensional. In this study, Hungary's migrant population was categorised into four large groups (dual citizens, foreign citizens, foreign-born citizens, and Hungarian citizen returnees). It also is important to note Hungary's position as a central area of remigration. In 2011, 190,204 persons in Hungary had lived abroad for at least one year, but had returned to Hungary and settled there.

\section{Acknowledgement}

This paper was supported by the János Bolyai Research Scholarship of the Hungarian Academy of Sciences.

Regional Statistics, Vol 5, No 2. 2015: 108-124; DOI: 10.15196/TS05206 


\section{REFERENCES}

BERnEK, Á. (2002): A globális világ politikai földrajza Nemzeti Tankönyvkiadó, Budapest.

BONACICH, E. (1972): A Theory of Ethnic Antagonism: The Split Labor Market. American Sociological Revein 37 (5): 547-559.

GÖDRI, I. (2010): A vándorlási veszteség Magyarországon az elmúlt évtizedben - avagy hányan is vagyunk valójában? Korfa 10 (3): 3 .

GÖDRI, I. (2012): Nemzetközi vándorlás In.: KSH NKI (2012): Demográfiai portré - jelentés a magyar népesség helyzetéröl pp. 137-154, Budapest.

Hatton, T. J. - Williamson, J. G. (2005): Global Migration and the World Economy: Two Centuries of Policy and Performance Mass.: MIT Press, Cambridge.

ILLÉS, S. (2008): Indirect estimation on the types of internatoinal elderly migration in Hungary Romanian Review on political Geography 8 (1): 55-63.

ILLÉS, S. - KINCSES, Á. (2009): Cirkuláció és migráció Magyarország nemzetközi vándormozgalmában Statisztikai Szemle 87 (7-8. szám): 729-747.

KAPITÁNY, B. - RoHR, A. (2013): A Magyarországon állandó lakcímmel rendelkező 18-49 éves magyar állampolgárok mintegy 7,4 százaléka tartózkodik jelenleg tartósan külföldön Korfa 13 (3): 3.

KINCSES, Á. (2012): A Kárpát-medence eqredforduló utáni migrációs hálózatának vizsgálata KSH, Budapest.

Kofman, E. - Youngs, G. (2003): Globalization: Theory and Practice Continuum, New York.

KovÁCs, É. - MELEGH, A. (2000): „Lehetett volna rosszabb is, mehettünk volna Amerikába is": Vándorlástörténetek Erdély, Magyarország és Ausztria háromszögében. In: Sik Endre-Tóth Judit (szerk.): Diskurzusok a vándorlásról pp. 93-152. Az MTA Politikai Tudományok Intézete Nemzetközi Migráció Kutatócsoport évkönyve, Budapest.

L. RÉDEI, M. (2009): A tanulmányi célú mozgás REG-INFO KFT. Budapest.

Nemes Nagy, J. (2009): Terek, helyek, régiók Akadémiai Kiadó. Budapest.

NÉMETH, Zs. (2011): Az urbanizáció és a térbeli társadalomszerkezet változása Magyarországon 1990 és 2001 között NKI, Budapest.

Portes, A. - DewIND, J. (2004): A Cross-Atlantic Dialogue: The Progress of Research and Theory in the Study of International Migration International Migration Review 38 (4): 828-851.

RAvenstein, E. G. (1885): The Laws of Migration Journal of the Royal Statistical Society 48 (2): $167-235$.

RÉDEI, M. (2005): A nemzetközi vándorlás folyamatának irányítása Statisðtikai Szemle 83 (7): 662-680.

RÉDEI, M. (2007): Mozgásban a világ, a nemzetközi migráció földrajza Eötvös Kiadó, Budapest.

TÓTH, P. P. (2005): A szomszédos országokból bevándorlók lakóhelyi és kulturális jellemzői Korfa 5 (2-3): 3-7.

VISZT, E. - PLANK, Zs. - BORSI, B. (2001): Mobility of Human Resources in Hungary: An Analysis and Proposal for Regular Collection of Statistics Hungarian Statistical Review 79 (6): 79-91.

WALDINGER, R. (2008): Between "here" and "there": Immigrant cross-border activities and loyalties International Migration Review 42 (1): 3-29.

Walton-RoberTs, M. (2004): Transnational Migration Theory in Population Geography: Gendered Practices in NetworksLinking Canada and India Population, Space and Place 10 (3): 361-373.

Williams, A. M. - BALAZ, V. (2008): International Migration and Knowledge Routledge. London.

Regional Statistics, Vol 5, No 2. 2015: 108-124; DOI: 10.15196/TS05206 